\title{
ПУБЛЦИСТИКА С. БАНДЕРИ 50-Х РОКІВ ХХ СТ: ОСНОВНІ ЗАСАДИ ВИЗВОЛЬНОЇ КОНЦЕПЦІї
}

\author{
Юлія Присяжна-Гапченко \\ Львівський національний університет імені Івана Франка, \\ вул. Генерала Чупринки, 49, 79044, Львів, Україна \\ e-mail: journft@franko.lviv.ua \\ https://orcid.org/0000-0001-9159-1042
}

У статті проаналізовано публіцистику С. Бандери 50-их років ХХ ст., зокрема йдеться про основні засади визвольної концепції. Автор на підставі аналізу статей С. Бандери означеного періоду стверджує, що в основу його визвольної концепції лягли такі основні ідеї і положення: головною і визначальною ідеєю була ідея української державності; основним засобом здобуття незалежності С. Бандера вважав національно-визвольну революцію; можлива світова війна не була для С. Бандери єдиним і визначальним чинником у боротьбі за українську державність; за союзників у боротьбі С. Бандера вважав лише ті політичні сили, які погоджувалися з ідеєю української державності; С. Бандера критикував Захід за пасивність у протистоянні з Радянським Союзом і небажання підтримувати визвольний рух поневолених Москвою народів; він розраховував як на національні рухи, так і на опір і незадоволення населення загалом у Радянському Союзі; допускав можливість співпраці 3 націонал-комуністами; не менш важлива, ніж попередні, ще одна ідея - вирішальною діючою силою революції є людина, яка в ім'я національних і вселюдських ідеалів бореться із совєтським імперіалізмом і людиноненависним комунізмом.

Ключові слова: публіцистика С. Бандери, ідея української державності, українська визвольна концепція.

Вступ. Над проблемами визвольної боротьби, яка повинна завершитися відновленням української державності, С. Бандера роздумував відразу після другої світової війни, коли ще в розпалі була збройна боротьба УПА, коли СРСР окупував кілька держав Східної Свропи (Польща, Чехословаччина, Угорщина, Румунія, Болгарія, Австрія), коли найбільші далекоглядні західні політики бачили загрозу для європейських цінностей з боку СРСР (промова Черчіля у Фултоні у травні 1946 року) коли провідні публіцисти українського збройного підпілля сподівалися на збройний конфлікт між недавніми союзниками - західними державами і Радянським Союзом, а ці сподівання ще більше зміцніли після початку війни в Кореї у червні 1950 року (П. Полтава написав велику статтю «Підготовка третьої світової війни та завдання українського народу» [12, 221-241].

(C) Присяжна-Гапченко Ю., 2019 
Одна $з$ перших публікацій С. Бандери, що стосувалася концепції визвольної боротьби, - це стаття «До засад визвольної боротьби» (1946р.). Згодом появилися й інші статті: - «Пляновість революційної боротьби в краю» (1948р.), «Слово до українських націоналістів-революціонерів за кордоном» (1948р.).

Упродовж 50-х років, останнього періоду свого життя, С. Бандера постійно роздумував над проблемою визвольної боротьби. Цей корпус публікацій починається статтею «Українська національна революція, а не тільки протирежимний резистанс» (1950р.) і завершується великою працею «Перспективи української національно-визвольної революції» (1959р.)

Постановка проблеми. Політичні сили будь-якої держави, яка втратила незалежність, зобов'язані роздумувати над планом відновлення державності, що передбачає розв’язання цілої низки проблем ідеологічного, організаційного, виховного, військового характеру. Це стосується і політичних партій української еміграції у 50-тих роках XX ст. Суть проблеми полягає в тому, яким у нових умовах (двополюсний світопорядок, наявність ядерної зброї, що загрожувала знищенням людства, агресивна політика СРСР і пасивність Заходу тощо) має бути шлях до визволення, на яких засадах має базуватися реальна концепція визвольної боротьби. Ситуація ускладнювалася і тим, що українська політична еміграція не була однорідною. Зазначимо, що в 50-тих роках можна виокремити кілька найбільш впливових політичних партій - ОУН під керівництвом С. Бандери, ОУН під керівництвом А. Мельника, ОУН за кордоном (Л. Ребет), УРДП (Українська революційно-демократична партія (І. Багряний). Для підтвердження цієї думки можна назвати статтю В. Маркуся «Місце, функція й призначення ЗЧ ОУН в українському політичному житті на еміграції» (ч. 23 «Українського самостійника» за 1956 р.). Проблеми визвольної боротьби широко обговорювалися на сторінках партійних видань. Це «Гомін України», «Шлях Перемоги», «Визвольний шлях» ОУН(б) тобто, Закордонні частини ОУН, «Українське слово», «Новий шлях», «Самостійна Україна» ОУН(м), «Український самостійник» (спочатку газета, а потім журнал), «Сучасна Україна» (ОУН за кордоном), «Українські вісті», «Український Прометей», «Наші позиції» (УРДП). Між політичними партіями української еміграції в 50-их роках не було одностайності у поглядах на шляхи і засоби визвольної боротьби і відновлення української державності. Так, Б. Кордюк, один із провідних діячів і публіцистів ОУН(з) зазначав: «війна не мусить бути ось-ось і ми не конче мусимо вернутись на Україну. Зрештою, ставка на близький конфлікт була все безглуздям, бо хоч збройного конфлікту не можна виключати, але $з$ другого боку недоцільно є вести політику тільки під єдиним аспектом, що такий конфлікт мусить постати. Це, вправді, не закон, але емпірична регула, що великі конфлікти не відбуваються безпосередньо один по одному» [8]. Аналізуючи український визвольний рух, А. Камінський, теж публіцист ОУН(3), стверджував, що у визвольній боротьбі потрібно поєднувати еволюцію й революцію, що боротьба повинна відбуватися в різних площинах і формах - легальних і нелегальних, організованих і стихійних, національних і соціальних, побутових і культурних, економічних і політичних - «суттєвим однак завжди буде їхнє остаточне цілеспрямування на скріплення власного національного потенціалу і визволення від окупанта» [6; 135]. У доповіді на III з'їзді УРДП І. Багряний заявляв: «Ми не ставимо ставки на війну. Ми ставимо ставки на революцію в СРСР. Підкреслюємо - СРСР, а не в якійсь його одній частині. Війна на якій будують свою політичну стратегію всі українські партії, 
якою може розв’язатися конфлікт між світом західної демократії й більшовицькою імперією, з нашого погляду може бути тільки щаблем до повного розвалу російської імперії, однією з передумов. Але до бажаної нам мети - до повного національного й соціального розкріпачення низки поневолених націй, а насамперед України, з низки причин війна може й не привести» $[1 ; 133]$.

Як бачимо, проблема шляхів визволення, правильного вибору засобів боротьби і союзників у цій боротьбі була предметом обговорення і дискусій в усіх найбільш впливових політичних партіях. Не стояли осторонь цієї проблеми і ЗЧ ОУН на чолі з С. Бандерою. Власне, ця політична сила дотримувалася найбільш радикальних поглядів на проблему. Бібліографія праць про С. Бандеру значна. Уже на початку 90-тих років, в роки незалежності, у нас перевидали працю П. Мірчука [10], згодом вийшла друком книга П. Дужого «Степан Бандера - символ нації» [5]. Тоді ж вийшла і книга П. Балея «Фронда Степана Бандери в ОУН 1940 року» [2].

Багато значних за обсягом праць появилося напередодні 100-річчя і 110-річчя від дня народження С. Бандери. Це і збірка документів радянських органів державної безпеки про С. Бандеру [15], і біографічний нарис Г. Гордасевич «Степан Бандера: людина і міф» [4], праці Я. Сватка «Місія Бандери» [14]. С. Перепічки («Феномен Степана Бандери») [11], М. Посівнича («Степан Бандера - життя присвячене свободі») [13], В. Кука («Степан Бандера. Роман Шухевич») [9].

Ці два збірники статей, де вже є суперечливі й 3 необгрунтованими звинуваченнями проти С. Бандери - «Степан Бандера: 1909 - 2009» [16], але особливо цим відзначаються окремі автори статей (Т. Снайдер, І. П. Хімка, К. Бондаренко, К. Александров) у збірнику «Страсті за Бандерою» [7]. Різноманітні джерела про С. Бандеру подано в бібліографічному збірнику «Люди боротьби й ідеї» С. Костя [7].

Актуальність дослідження зумовлена необхідністю в умовах нинішньої російсько-української війни критично осмислити як новітній досвід захисту української державності, так і досвід відомих українських діячів минулого, зокрема С. Бандери.

Мета статті - з'ясувати основні засади (суть поглядів С. Бандери на визвольну концепцію, на засоби, рушійні сили, на можливих союзників цієї боротьби, на перспективи української революції, на умови, в яких може відбутися відновлення української державності, визвольної концепції С. Бандери).

Виклад матеріалу. Уже в першій великій праці, що появилася на початку п'ятдесятих років, у статті «Українська національна революція, а не тільки протирежимний резистанс» (1950) С. Бандера обгрунтував низку важливих і принципових ідей, що стосувалися визвольної боротьби. Так, він конкретизував саме розуміння визвольної боротьби, бо розумів цей процес як українську національну революцію і визначив мету цієї революції. Стаття була спрямована проти ворогів України, зокрема проти більшовицької Москви, яка «слушно вбачає в українському націоналістичному, революційному визвольному русі найнепримиреннішого, найнебезпечнішого ворога, що безупинно веде боротьбу з нею на всіх фронтах і відтинках... Наша боротьба з Москвою ведеться скрізь, в Україні, серед інших народів, поневолених більшовизмом, і на закордонних теренах» [3; 133]. (Зазначимо, що С. Бандера полемізував зі своїми опонентами із середовища української еміграції, зокрема з I. Багряним; С. Бандера обгрунтував шкідливість гасла «За демократичний лад в Україні» замість гасла «За самостійну національну державу»). На думку С. Бандери, головним при- 
значенням і змістом українського націоналістичного руху є державна суверенність і соборність України, а здобути це можна лише власною реальною революційною боротьбою. Він зазначав: «Наша визвольна боротьба - це концепція чину, боротьби...» [3; 161]. С. Бандера розумів потребу цієї боротьби «на всіх ділянках життя, широким фронтом, різними формами, як постійно діючий і всезростаючий процес, аж до повної перемоги. Революційне змагання - це національна боротьба в площині духовости, культури, боротьба суспільно-політична і мілітарна, за повне знищення існуючого стану, його змісту й за побудову цілком нового, під кожним оглядом кращого стану, який відповідає потребам і бажанням українського народу. Збройна боротьба творить суттєву складову частину цілої революції. Всенародне повстання, збройний зрив цілого народу й остаточне повалення фізичної підстави та сили ворога у відповідний момент має завершити визвольну боротьбу, забезпечити будування самостійної держави, ладу, національної і соціальної свободи» [3;140]. Отже, навіть у 1950 році С. Бандера не покладався лише на можливий вибух війни між США та їхніми союзниками проти СРСР. Він не погоджувався з тими, хто визнавав лише збройну боротьбу, нехтуючи іншими видами боротьби. С. Бандера стверджував, що загальна політична ситуація, яка склалась після війни, «зробила неможливим щораз більше поширення мілітарних дій, розгортання повстанчих операцій. Прийшов період всебічного й глибинного революційного процесу, в якому міліарний бік служить підсиленням суспільно-політичних секторів революції.

Отже, основні ідеї цієї праці С. Бандери можна сформулювати так:

- українська визвольна боротьба - це національна революція, яка повинна допровадити до здобуття Української Самостійної Соборної Держави, а не лише до знищення більшовицького режиму, це не протирежимна боротьба, а історична боротьба України з Росією;

- збройна боротьба - це важливий складник революції, але революційний процес повинен охоплювати й інші ділянки суспільного життя;

- процес збирання, плекання, формування власної сили визвольної революції повинен відбуватися на засадах українського революційного націоналізму, визвольна концепція, ідеологія і програма якого повинні чітко відображати прагнення українського народу.

Цим не вичерпується ідейно-концептуальний зміст статті. Так С. Бандера висловив думку про орієнтацію на власні сили. Він вказував на те, що західні держави у своїй зовнішній політиці мало уваги приділяють долі тих народів, що їх поневолив Кремль. Зазначимо, що С. Бандера критикував Захід не лише з цього приводу, i цей напрям критики С. Бандера розвине в наступних публікаціях обгрунтування. В революційному процесі значення збройна боротьби не означав, що С. Бандера нехтував відомими загальнолюдськими цінностями. У цьому можна переконатися на підставі його ставлення до демократичних засад. С. Бандера зазначав: «Між ідеями і гаслами треба відрізняти такі, що мають універсальне значення, які приймаємо й ними оперуємо так само, як іншими силами. Сюди належать гасла демократії і різні загальнолюдські ідеї, кличі. Від них відрізняємо такі кличі, які мають найсуттєвіший $\mathrm{i}$ цілком конкретний зміст наших власних цілей, $\mathrm{i}$ через те $\epsilon$ нашими, прапорними» [3; 160]. С. Бандера заперечував те розуміння демократії, яку нав’язувала радянська пропаганда, він писав, що може лише гидитися більшовицькою безсоромністю, коли СРСР виступає в позі демократизму, як речник і захисник «найсправжнішої де- 
мократії». Але С. Бандера критикував і Захід, який сприймав більшовицьку брехню за правду. Важливо і те, що С. Бандера, як уже зазначалося, критикував ті українські політичні сили на еміграції, які намагалися нав’язати визвольній боротьбі гасло «за демократію» як головне, як прапорне.

У цій праці С. Бандера сформулював ще одну дуже важливу думку, про яку треба сказати окремо, бо iï актуальність підтверджується і сьогодні, в умовах російсько-української війни. Зацитуємо цю думку: «Протиставна до націоналістичної визвольної концепції концепція тільки протирежимного резистансу має ще одну засадничу, неправильну й шкідливу підставу. Прихильники самого протирежимного резистансу борються лише проти більшовизму і його імперіалізму, а не проти Росії, тим більше, сохрани Боже, не проти російського народу. Бо, мовляв большевизм і російський імперіалізм нібито відділені від російського народу, який за його імперіалізм не відповідає, його не хоче, не підтримує, а навпаки, хоче його повалити [1; 166]. Натомість С. Бандера стверджував, що генеральна лінія української визвольної політики базується на тому, що боротьба за державну незалежність України - це боротьба не просто проти Росії, а це боротьба проти російського більшовизму і проти кожного загарбницького російського імперіалізму, що притаманний російському народові і в минулому і тепер. На думку С. Бандери, якщо «завтра на зміну большевизмові прийде інша форма російського імперіалізму, то він так само насамперед звернеться всіма своїми силами проти самостійности України, на їі поневолення» $[3 ; 166]$.

Основні засади визвольної концепції, висловлені у цій праці, залишалися практично незмінними і в наступних працях, хоча, залежно від міжнародної ситуації, С. Бандера міг деякі формулювання уточнювати, доповнювати, - це не означало ревізії принципових, фундаментальних поглядів на проблему здобуття української державності. Так, у статті «Фронт поневолених націй» (1950р.) С. Бандера обгрунтував ідею спільного національного визвольного Фронту всіх поневолених російською імперією народів і вважав це досягненням революційної політики українського націоналізму. (Ще в листопаді 1943 року з ініціативи ОУН було створено Антибільшовицький блок народів, який був покликаний координувати визвольну боротьбу народів, які поневолила більшовицька Росія; АБН був, як зазначав С. Бандера, організаційним політичним завершенням ідеї спільної революційно-визвольної боротьби всіх поневолених Москвою націй; ця структура існувала і на еміграції). Практичним відображенням цієї ідеї був той факт, що в УПА воювали представники багатьох інших народів. На думку С. Бандери, українська політична еміграція у своїй національно-визвольній політиці занедбала фронт поневолених націй. У цій статті С. Бандера висловив кілька принципових ідей: націоналізм вільної від чужоземного панування нації з морально-етичного погляду відповідальний за всяке насильство і поневолення іншої нації, де б воно на земній кулі не відбувалося (С. Бандера апелював до західних держав), тим більшою і конкретнішою є політична і моральна відповідальність українського націоналізму як найбільшої сили, що протистоїть московському імперіалізмові в боротьбі за долю поневолених народів (С. Бандера, очевидно, мав на увазі боротьбу на території окупованої України, на іiї західних землях і боротьбу прибалтійських народів); повною і найвищою перемогою українського націоналізму буде стан, коли російська імперія перестане існувати $\mathrm{i}$ всі поневолені народи здобудуть незалежність; Україна перебуває в центрі фронту 
поневолених народів; фронт поневолених націй у принципі відкидає політику т. зв. «безкровного» визволення, тобто політику, яка не завершується безпосередньою революційною визвольною війною поневоленої нації проти окупанта; і ще одна важлива думка - фронт поневолених націй - це взаємопізнання історії, культури, міжнаціональних взаємовідносин, соціальних систем, релігії поневолених Москвою націй (але пізнавати потрібно з національних джерел, а не крізь «московське густе сито або в її кривому дзеркалі» [3;203]); географія дій фронту поневолених націй - від «залізної завіси» до Тихого Океану, і представник кожної поневоленої нації є й буде вояком УПА, як і українець за межами України буде вояком тамтешньої національної УПА, воюючи за Україну.

До цієї проблеми С. Бандера повернувся згодом і в статті «Завдання ОУН під сучасну пору» (1951), про це йдеться в першій частині статті під назвою «Завдання ОУН в Україні».

Агресивна політика СРСР спонукала С. Бандеру звернутися до аналізу проблеми визвольної боротьби у зв'язку з можливою третьою світовою війною. Одна із перших публікацій на цю тему - стаття «Війна в Кореї і національно-визвольна політика» (1950). Наступні публікації - «Третя світова війна: визвольна боротьба» (1950), «Питання атомової війни і визвольна революція» (1957-1958), а також його остання стаття «На півметі» (1959).

У статті «Війна в Кореї і національно-визвольна політика» С. Бандера уточнив концепцію української визвольної боротьби і зазначав, що у політиці західних держав, а зокрема і США відсутнє позитивне ставлення до української визвольної боротьби та її мети - знищення більшовизму, російського імперіалізму, розподілу СРСР і побудови незалежних національних держав. Поки західні держави не йтимуть на повне знищення російського більшовизму й імперіалізму, на розвал СРСР і відродження національних держав, а прагнуть лише до припинення більшовицької агресії і експансії, доти нема підстав пов’язувати визвольні змагання з політикою західних держав і їхніми конфліктами.

У статті «Третя світова війна і визвольна боротьба» С. Бандера ще докладніше обгрунтовував концепцію визвольної боротьби у зв'язку з можливістю вибуху третьої світової війни. С. Бандера зазначав, що війна в Кореї «надала розвиткові міжнародної ситуації настільки виразні перспективи і темпи, що можливість третьої світової війни стає серйозним чинником у всяких політичних членуваннях, навіть на недалеку мету» $[3,204]$. У зв'язку з цим С. Бандера наполягав на тому, що й українські визвольні змагання повинні брати до уваги міжнародну ситуацію, яку й вони, зрештою, формують; проте, на його думку, такий підхід правильний лише тоді, коли він спирається на влучний аналіз та оцінку ситуації, зокрема на оцінку політичної позиції противників СРСР. С. Бандера задавав принципове питання: «чи західні держави, зокрема США при такій нашій поставі видвигнуть справу державної самостійности України як одну із цілей війни, так, щоб це їх зобов'язувало в подальшому і давало якісь гарантії? А дальше питання - чи в їхній політиці нема таких елементів, які змагають до чогось іншого, які не дають місця для змагання за суверенність $i$ соборність України в рамцях їхнього комплексу?» [3;204]. Позитивної відповіді на це питання С. Бандера слушно не давав, і це свідчить про його розважливе обдумування проблеми. Він мав рацію, бо західних держав цікавило знищення більшовизму, а не імперіалістичної Росії і сформулював цей висновок так: «Ціла дотогочасна 
й сьогоднішня політика західних держав, зокрема США, не дає підстав і стійких аргументів для позитивної в сенсі цієї концепції відповіді на поставлені питання. Те все, що у відношенні до української справи має місце в американській політиці, а властиво треба сказати, що немає місця, бо вона насправді цілком ігнорує українське питання - не дає жодної точки зачепу, опертя для ставлення такої концепції українського визволення» [3, 206].

Політику західних держав щодо СРСР С. Бандера визначив як політику самообману. Але він доводив ще одну тезу - такою ж оманною була і ставка Заходу «на відщеплення імперіалістичних тенденцій російського народу і большевизму» $[3,206]$. На думку С. Бандери, Захід хоче «звільнитися лише від смертельної загрози большевизму, найгіршої форми російського імперіалізму» $[3,216]$, Вони не хочуть зачіпати імперіалістичних настроїв російського народу. Це зумовлювало і ставлення Заходу до визвольних рухів поневолення народів - вони мали боротися проти більшовизму, але не прагнути до незалежності. Ще один важливий момент, на якому наголосив C. Бандера, - таку політику західних держав підтримує і російська еміграція, яка ще $з$ часів генерала Власова намагалася підпорядкувати собі визвольні рухи поневолених в Росії народів. Як бачимо, у С. Бандери було досить підстав, щоб означити політику західних держав як фальшиву і згубну, «сама війна в такій постановці не несла б нам визволення. Повалення самого большевизму, а реставрування російської імперії в новій формі, в якій Україна далі мала б бути поневолена Росією - це для нас не є жодна розв'язка. Така справа для нас не варта найменшої жертви, а не то тих велетенських жертв, які війна буде коштувати наш народ, нашу країну» $[3 ; 220]$. Таким чином, на думку С. Бандери, третя світова війна так само як і дві попередні не принесе Україні визволення й державної незалежності. Саме тому С. Бандера наголосив на тому, що єдиний шлях, на якому можна здобути справжнє визволення і державну суверенність, - це українська національна революція, боротьба української нації проти більшовицької Росії, «нарід може здобути справжнє і тривке визволення тільки власним змаганням, напругою всіх своїх сил у боротьбі на життя і смерть» [3; 222].

С. Бандера уточнив форму цієї національної революції - вона має відбутися у формі тотальної війни України з Росією, в його розумінні протибільшовицька революція - це подолання більшовизму боротьбою цілого народу зсередини, а найважливіший момент революції - це боротьба у всіх формах і на всіх ділянках організованого суспільного життя» передусім боротьба політично-мілітарна, яка 3 перманентної революційної дії підпільних сил, з організованих ними і спонтанних революційних акцій щораз ширших кіл, має перейти у загальне повстанче піднесення цілого народу» [3; 223]. На думку С. Бандери, в СРСР існує основне підгрунтя для протибільшовицької революції - глибоке невдоволення найширших народних мас. Він наголошував на безкомпромісності більшовицького терору, а тому й підкреслював, що революційна боротьба проти більшовизму буде вимагати дуже великих жертв, на що спроможні ті, що свідомо готові до нього. На таку жертву підуть не лише з ненависти до радянського ладу, а й з великої ідеї - С. Бандера мав на увазі державницьку ідею, національну ідею свободи. Вказав він і на ту активну революційну силу, що «своїм чином дає приклад, вказує шлях, пориває щораз ширші кола в струм своєї боротьби, дає їй напрям, організує, проводить» [3; 225]. Існування такої революційної сили він вважав вирішальним чинником для виникнення й розвитку революції. 
С. Бандера розраховував і на протибільшовицький революційний зрив інших поневолених народів у більшовицькій Росії.

С. Бандера намагався передбачити розвиток подій у разі виникнення світової війни, його міркування не можна вважати абстрактними, бо вони, справді, опиралися на аналіз конкретної міжнародної ситуації. Але війна не вибухала, а тому й зрозуміло, чому С. Бандера дійшов такого висновку: «Правильна й єдино реальна концепція визволення України - це власна революційна боротьба...» [3; 231], проте все ж додає: «теж на випадок недалекої світової війни». I все ж основна теза цієї статті - тільки шляхом революційної боротьби український народ може взяти владу в свої руки і збудувати незалежну державу.

До питання національної революції С. Бандера повернувся і в статті «За правильне розуміння визвольно-революційного процесу» (1955), в якій він аналізує діяльність ОУН після Другої світової війни, полемізує з тими, хто покладав надії на західні держави. У цій статті С. Бандера знову пропонував розглядати національну революцію і революційно-визвольний рух ширше, ніж рух суто воєнний. Проте $\epsilon$ ще одна важлива стаття, в якій С. Бандера піднімає питання визвольної боротьби у зв'язку з світовою війною - «Питання атомової війни і визвольна революція» (1957). С. Бандера вважав, що протистояння між західним світом і СРСР, яке триває дванадцять років, західні держави могли вирішити на свою користь відразу після розгрому Німеччини. Це було б логічно, і це узгоджувалося б із сподіваннями поневолених народів. Умови для цього були - воєнна перевага Заходу і національно-визвольний рух поневолених народів (С. Бандера повторював міркування і аргументи публіцистів українського збройного підпілля - одначе «політика Заходу пішла проти здорового глузду, далеко поминаючи інтереси не тільки поневолених народів, але й свої власні» [3; 422].

Наступні тези цієї статті - західним державам не вистачає волі й рішучості, щоб протистояти експансії СРСР; якщо атомна зброя в руках США не зупинила московську експансію, то нема підстав сподіватися, що це станеться тепер, коли нею володіють і більшовики; новітня воєнна техніка (С. Бандера мав на увазі атомні і водневі бомби) виконує негативну роль: «В образі модерної війни виявляється ввесь трагізм сучасної цивілізації, причиною якого $€$ те, що впарі з матеріяльно-технічним поступом не йде відповідне духовно-моральне піднесення людей і народів» [3; 435]. Ця думка, до речі, вперше появилась у публіцистиці С.Бандери. Це стосується і наступної думки: «Вирішальною діючою силою революції є людина, яка в ім'я найвищих національних і вселюдських ідеалів веде боротьбу з московсько-совєтським імперіялізмом і людиноненависним комунізмом» [3; 435]. Щодо війни - антибільшовицька національно-визвольна революція розраховує на інший, протилежний спосіб дії, ніж модерна війна; війна сприяє розгортанню революційної боротьби; якщо Захід почне війну з СРСР, але не буде мати на меті визволення поневолених народів, то вони не будуть сприймати цю війну як визвольну і тоді революційно-визвольні сили повинні організувати революційну боротьбу самостійно; новітня зброя диктує інші способи ведення війни, i це потрібно врахувати у визвольній боротьбі. Крім цього С. Бандера постійно наголошував на пасивності й нерішучості Заходу, на його страхові перед війною з СРСР (С. Бандера, може, не здавав собі справи із наслідками ядерної війни), на небажанні створити спільний фронт усіх протибільшовицьких сил. 
Увагу привертає останній абзац статті: «Хоч большовицька система створює дуже важкі умови для визвольної революційної діяльности, проте вона викликає серед усіх поневолених народів та у всіх ділянках життя стільки протибольшевицьких настроїв, прагнень і ферментів, що вибух загальної визвольної революції мусить неухильно прийти» [3; 449]. Так і сталося, але майже через тридцять років і за інших умов, ніж це передбачав С. Бандера.

Остання велика праця С. Бандери - «Перспективи української національно-визвольної революції» (1958). Як відомо, вона була призначена для внутрішнього користування. По суті, це узагальнення і підсумок усієї політичної та публіцистичної діяльності С. Бандери у повоєнний період. У першому розділі («Необхідність національно-визвольної революційної боротьби») С. Бандера зазначав: «Поскільки визвольно-революційна боротьба є необхідною для життя і розвитку української нації, то нема чого зупинятися над питанням, чи вона є можливою, тільки відразу треба шукати відповідних доріг і способів для її успішного ведення» [3; 477]. У другому розділі («Московський імперіялізм і комунізм - дві форми одного ворога») С. Бандера підкреслював, що імперіялізм російського народу - це явище історичного порядку, що міняє свої форми та методи дії, але в своїй суті залишається незмінним, а комунізм став однією з форм і головним засобом московського імперіялізму. У третьому розділі («Можливості докорінних змін на підбольшовицькому обширі») С. Бандера явно перебільшував можливості боротьби проти СРСР на його теритоpiї, але вказав на три основні теоретичні можливості змін на підбільшовицькому просторі: 1) усунення більшовизму зовнішніми силами (тобто війною); 2) внутрішня еволюція більшовизму, глибинні зміни в більшовицькій системі, в режимі та його національній, суспільній, економічній, культурній політиці; 3) це протибільшовицька революція, насамперед національно-визвольна революція поневолених Москвою народів. На його думку, крім цих основних можливостей (а вони відображали певні політичні концепції, за якими стояли українські чи чужоземні політичні сили) $є$ ще й різні комбінації цих можливостей. У четвертому розділі («Значення війни для національного визволення») С. Бандера повторив свої попередні міркування з приводу війни як чинника національно-визвольної боротьби, про значення воєнної ситуації для визвольної боротьби. С. Бандера зазначав, що війна між СРСР та іншими державами напевно принесла б українському народові нові великі жертви в людях і велике спустошення, але жертви і всебічні втрати, що їх зазнає Україна у більшовицькій неволі, значно більші і гірші, ніж були б у результаті війни (цю думку С. Бандера висловлював і раніше - у статті «Хоч які великі жертви - боротьба конечна», написаній на Різдво в 1956 р.). С. Бандера вважав виникнення війни між західними державами та СРСР бажаним для визвольної справи, але не намагався передбачити спустошення і жертви в результаті використання неконвенційної, а ядерної зброї. У підсумкових висновках цього розділу С. Бандера окреслив своє бачення проблеми «війна і визвольна боротьба»:

- сама війна між західними державами та СРСР не принесла би національного визволення поневоленим народам, бо їх не державна самостійність не входить у концепцію Заходу;

- така війна створить корисніші умови для національно-визвольної боротьби ніж мирна ситуація; 
- $з$ розвитком війни національно-визвольні рухи можуть мати проти себе нові фронти;

- у разі війни національно-визвольні рухи повинні використати цей факт і розвинути свою власну, зокрема збройну боротьбу;

- генеральна директива для всіх поневолених народів - творити власну революційну збройну силу і займати активну поставу, виявляти ініціативу і діяти згідно $з$ рацією національно-визвольних змагань.

Основна ідея розділу «Еволюція большевизму і частинні здобутки боротьби» нема жодної підстави покладати надії на еволюційні зміни в більшовицькій системі, бо ці зміни не перетворюють більшовизм в неімперіалістичну і прийнятну для народів систему; щось здобути можна лише протибільшовицькою боротьбою. Розділ «Протибольшевицька революція - єдиний шлях до визволення» - це повторення того, що С. Бандера висловлював уже раніше: 1) війна проти СРСР не може бути головною ставкою для визвольних змагань; 2) еволюція більшовицької системи теж не приведе до визволення; 3) третя можливість - революційна боротьба. У цьому розділі С. Бандера визначив основні функції і роди революції, реальні сили революційної визвольної концепції (ідея власних сил). Дуже цікава думка проте, що в радянському режимі в народі дрімає величезний революційний потенціал, який потрібно організувати і використати. Подібну думку висловлював і І. Багряний.

У розділі «Національно-визвольна революція і російські протикомуністичні сили» С. Бандера висловив думку, що протирежимні настрої теж існують серед російського народу. Він схарактеризував російські протикомуністичні елементи. (Раніше С. Бандера висловлював думку про органічну єдність таких структур - російської нації, російського імперіалізму і російського більшовизму, наприклад, у статті «Первородний гріх проросійської концепції», неодноразово наголошував він і на імперіалістичних настроях російського народу). С. Бандера вважав, що протикомуністичні російські сили треба використати у визвольній боротьбі.

Цілком зрозумілою $є$ й ідея розділу «Спільний Фронт національно-визвольних революцій». С. Бандера наголосив на тому, що всі народи, які борються за національне визволення проти Москви, є природними союзниками. Він схарактеризував концепцію спільного визвольного фронту, вказав на його політичні вияви (Антибільшовицький блок народів, узгоджені політичні платформи як підстава спільних політичних дій, організація спільних зовнішньополітичних акцій, зв'язки і співпраця між окремими національно-визвольними рухами тощо).

Окремий розділ присвячено аналізові ставлення до націонал-комуністичного фронту. Під націонал-комунізмом С. Бандера розумів таку ідеологічно-комуністичну концепцію, яка має на меті побудову або збереження самостійної держави якого народу з комуністичним устроєм. Можна припустити, що С. Бандера знав історію українського націонал-комунізму 20-х років, вивчав досвід націонал-комунізму в європейських країнах. С. Бандера підкреслив, що український націоналізм ставиться негативно до націонал-комунізму, що його треба усунути з України. Проте з націонал-комуністами можна співпрацювати тоді, коли нема ще грунту для національно-визвольного руху, а націонал-комуністи ведуть боротьбу з Москвою за державну самостійність України. В іншому разі з ними треба боротися.

В останньому розділі («Розвиток і чинники революційного процесу») С. Бандера схарактеризував діючі сили революції (основи і головний зміст революційної 
визвольної концепції він з'ясував у шостому розділі). С. Бандера зазначав: «Є три основні первісні рушії революційного процесу: революційна ідея, революційна організація і революційна акція» [3; 535]. У цьому розділі С. Бандера схарактеризував цілі революційної боротьби, діючі сили. Він підкреслював: «Програмові засади українського націоналізму визначають напрямні, до яких зміряє революційна перебудова усіх ділянок життя. Але необхідні переходові етапи і форми цієї перебудови у визвольно-воєнному періоді мусять бути максимально достосовані до тих вимог, що їх кожночасно диктує визвольна й оборонна стратегія в широкому розумінні - мілітарному, політичному, економічному й ідеологічно-духовному [3; 557]. Такий підхід свідчив про конкретність аналітичного мислення С. Бандери.

Висновки. Узагальнивши сказане, можна так визначити основні ідеї і положення, що лягли в основу визвольної концепції С. Бандери: головною і визначальною у його визвольній концепції була ідея державності; основним засобом на шляху до державності С. Бандера вважав національну-визвольну революцію; до світової війни С. Бандера ставився як до масштабної події, що може посприяти національному визволенню, але це не був для нього чинник єдиний і визначальний; за союзників у боротьбі С. Бандера вважав лише тих, хто погоджується з ідеєю української державності.

\section{REFERENCES}

1. Багряний I. Публіцистика: Доповіді, статті, памфлети, рефлексії, ece / Упоряд. О. Коновал; передм. І. Дзюби; післям. Г.Костюка. К.:Смолоскип, 1996. 856 с.

2. Балей П. Фронда Степана Бандери в ОУН 1940 року. Київ, 1996. 210 с.

3. Бандера С. Перспективи української революції. К., 1999. 622 с.

4. Гордасевич Г. Степан Бандера: людина і міф. Львів: Апріорі, 2008. 208 с.

5. Дужий П. Степан Бандера - символ нації. Ескізний нарис про життя і діяльність Провідника ОУН: у двох частинах: частина перша. Львів: «Галицька Видавнича Спілка», 1996. 190 с.; його ж. Степан Бандера - символ нації. Ескізний нарис про життя і діяльність Провідника ОУН: у двох частинах: частина друга. Львів: «Галицька Видавнича Спілка», 1997. 383 с.

6. Камінський А. Динаміка визвольної боротьби. Б. м. в.: Сучасність, 1973. 236 с.

7. Кость С. Західноукраїнська преса першої половини ХХ ст. (люди боротьби й ідеї): бібліографічний покажчик. Львів: Видавничий центр ЛНУ, 2018.

8. Кордюк Б. Завдання української визвольної політики в період коекзистенції // Український самостійник. 1956. Ч. 39.

9. Кук Б. Степан Бандера. Роман Шухевич. Львів: ПП «Вид-во «Бона», 2012. 144 с.

10. Мірчук П. Степан Бандера. Символ революційної безкомпромісовости. Хмельницький: Поділля, 1992. 144 с.

11. Перепічка С. Феномен Степана Бандери. Львів: Сполом, 2013. 744 с.

12. Полтава П. Збірник підпільних писань. Мюнхен, 1959. 297 с.

13. Посівнич М. Степан Бандера - життя, присвячене свободі. Торонто; Львів: Вид-во «Літопис УПА», 2008. 110 с.

14. Сватко Я. Місія Бандери. Львів: «Галицька Видавнича Спілка». 2008. 64 с.

15. Степан Бандера у документах радянських органів державної безпеки (1939-1959). К.: ПП Сергійчук М. I., 2009. Т. 1. 680 с.: Т. 2. 630 с.: Т. 3. 648 с. 
16. Степан Бандера: 1900-2009: Зб. статей / Упоряд. Богдан Гордасевич, Микола Посівнич. Львів: «Тріада плюс», 2010. 218 с.

17. Страсті за Бандерою: статті, есеї / Упоряд. Т. С.Алмар, І. Балинський, Я. Гриник. Київ: Грані, 2010. 400 с.

\title{
PUBLICISM S. BANDERI 50-X YEARS XX ST: THE BASIC TERMS OF THE EXTRA CONCEPT
}

\author{
Julia Prysyazhna-Gapchenko \\ Ivan Franko National University of Lviv, \\ Generala Chuprynky Str., 49, 79044, Lviv, Ukraine \\ e-mail:journft@franko.lviv.ua \\ https://orcid.org/0000-0001-9159-1042
}

The article analyzes S. Bandera's journalism of the 50-ies of the twentieth century, in particular, the basic principles of the liberation concept.

On problems of the liberation struggle, which should be completed by the restoration of Ukrainian statehood, S. Bandera began to reflect immediately after the end of the Second World War. The basis for such a conclusion is -his article «To the Basics of the Liberation Struggle» (1946), «The Plinyness of the Revolutionary Struggle in the Territory» (1948), «The Word to the Ukrainian Nationalist Revolutionaries Abroad» (1948).

Even more attention to S. Bandera attached to this problem in articles written in the 50 years. These are such works as «Ukrainian National Revolution, not only anti-regime resistibility» (1950), «The Front of Assured Nations» (1950), «The War in Korea and the National Liberation Policy» (1950), «Third World War: Liberation struggle «(1950),» The task of the OUN in modern times» (1951), «The Atomic War and the Liberation Revolution» (19571958), «The Prospects for the Ukrainian National Liberation Revolution» (1959), - this is the latest large publication by Bandera.

The article shows that journalists of other Ukrainian political parties also thought about the problem of obtaining Ukrainian statehood. Bandera controversy with those who did not believe in the success of the liberation struggle, who did not support the idea of Ukrainian statehood.

The author argues that underlying the liberation concept of S. Bandera were the following basic ideas: the main and decisive was the idea of Ukrainian statehood; the main means of obtaining statehood S. Bandera considered the national liberation revolution; a possible World War was not the only and determining factor for S. Bandera in gaining statehood; For allies S. Bandera considered only those political forces that supported the idea of Ukrainian statehood; Bandera criticized the West for its passivity in confronting the Soviet Union and the reluctance to support the liberation movement of the Moscow-enslaved peoples; he counted on both the national movement and the resistance and dissatisfaction of the population in general and the Soviet Union; allowing for cooperation with National Communists; no less important than the previous ones, another idea - the decisive active force of revolution; a person who, in the name of national and all-human ideals, fights Soviet imperialism and human-hated communism.

Key words: S. Bandera's journalism, ideas of Ukrainian statehood, Ukrainian liberation concept. 